\title{
VEGF suppresses epithelial-mesenchymal transition by inhibiting the expression of Smad3 and miR-192, a Smad3-dependent microRNA
}

\author{
JUN-PING HONG, XUE-MEI LI, MING-XI LI and FA-LEI ZHENG \\ Division of Nephrology, Peking Union Medical College Hospital, Beijing 100730, P.R China
}

Received February 5, 2013; Accepted March 27, 2013

DOI: $10.3892 /$ ijmm.2013.1337

\begin{abstract}
Transforming growth factor- $\beta 1$ (TGF- $\beta 1$ )-induced epithelial-mesenchymal transition (EMT) is one of the important cellular and molecular mechanisms involved in renal fibrosis. Smad3 and miR-192 (a Smad3-dependent microRNA) are involved in TGF- $\beta 1$-mediated EMT. Vascular endothelial growth factor (VEGF) is a renal tubular epithelial survival factor. Therefore, in the present study, we investigated the role of Smad3 and miR-192 in the effects of VEGF on TGF- $\beta 1$-mediated tubular EMT. A human kidney cortex (HKC) cell line stably overexpressing VEGF (HKC-SOEV) was established. The normal HKC cells and HKC-SOEV cells were treated with TGF- $\beta 1(5 \mu \mathrm{g} / \mathrm{l})$ or/and LY294002 (20 $\mu \mathrm{mol} / \mathrm{l})$ for 24 and $48 \mathrm{~h}$ (LY294002 blocks the effect of VEGF). The protein expression of Smad2, Smad3, Smad4 and phosphorylated Smad3 (p-Smad3) were measured by western blot analysis. The expression of Smad3 and miR-192 was determined by real-time PCR. E-cadherin and $\alpha$-smooth muscle actin ( $\alpha$-SMA) expression was detected by western blot analysis and laser scanning confocal microscopy (LSCM). TGF- $\beta 1$ was found to induce the expression of $\alpha$-SMA in the HKC cells. TGF- $\beta 1$ also induced Smad3, miR-192 and p-Smad3 expression, but suppressed E-cadherin expression. However, in the HKC-SOEV cells, the expression levels of $\alpha$-SMA, Smad3, miR-192 and p-Smad3 upon TGF- $\beta 1$ stimulation were significantly reduced. In these cells, the suppressive effect of TGF- $\beta 1$ on E-cadherin was also reduced. Importantly, treatment with LY294002 significantly diminished the effect of VEGF. VEGF suppressed Smad3 and miR-192, and subsequently inhibited EMT induced by TGF- $\beta 1$.
\end{abstract}

Correspondence to: Professor Fa-Lei Zheng, Division of Nephrology, Peking Union Medical College Hospital, No. 1 Shuaifuyuan, Wangfujing, DongCheng District, Beijing 100730, P.R. China E-mail: yccfmn@sina.com

Key words: Smad3, miR-192, vascular endothelial growth factor, epithelial-mesenchymal transition

\section{Introduction}

The development of renal interstitial fibrosis is closely associated with the progression of chronic kidney disease, which eventually leads to renal failure. Increasing evidence suggests that renal tubular epithelial-mesenchymal transition (EMT) plays an important role in renal interstitial fibrosis (1), and that EMT is one of the cellular and molecular mechanisms involved in renal interstitial fibrosis (2). EMT is a phenomenon whereby epithelial cells transform into mesenchymal cells under specific physiological and pathological conditions. The transformation begins with a reduction or loss of expression of the epithelial cell marker, E-cadherin, followed by the disruption of tight junctions, rearrangement of the cytoskeleton, the induction of mesenchymal cell markers, such as $\alpha$-smooth muscle actin ( $\alpha$-SMA), and the destruction of the basement membrane, which allows for the migration of transformed cells to the interstitial compartment (3-5).

The involvement of EMT in fibrosis is internationally controversial, and the controversy stems from the fact that it is difficult for pathologists to observe EMT-like morphological changes. This is mainly due to the fact that the EMT process is extremely short, and is not easy to capture. However, increasing evidence indicates that fibroblasts in the fibrotic disease process are not only derived from mesenchymal stem cells in bone marrow or the body organs, but they may also be the same cells from the injured tissues following EMT $(1,6)$. Evidence indicates that epithelial cells are an important source of muscle fibroblasts in the process of fibrosis (7). In vivo evidence of EMT has been observed in animal models of obstructive nephropathy (8), diabetic nephropathy (9) and 5/6 nephrectomy remnant kidney (10).

Transforming growth factor- $\beta 1$ (TGF- $\beta 1$ ) mediates renal fibrosis by inducing the transformation of tubular epithelial cells into myofibroblasts through EMT (10). TGF- $\beta 1$ is formed as a ligand receptor complex. At the cell surface, it is now well established that the binding of TGF- $\beta 1$ to its type II receptor (T $\beta$ RII) can activate the TGF- $\beta$ receptor type I (T $\beta$ RI)-kinase, resulting in the phosphorylation of Smad2 and Smad3, 2 recepor-associated Smads (R-Smads). Subsequently, phosphorylated Smad2 and Smad3 (p-Smad2 and p-Smad3) bind to the common Smad4 and form the Smad complex, which translocates into the nucleus to regulate target gene transcription (11). 
miR-192 is a TGF- $\beta$-dependent microRNA, and during renal fibrosis it is tightly regulated by TGF- $\beta 1$ via $\operatorname{Smad} 3$ (12), and miR-192 is expressed in mesangial cells and renal tubular epithelial cells $(13,14)$. It has been demonstrated that miR-192 regulates the expression of Smad-interacting protein 1 (SIP1) [also known as Zinc finger E-box-binding homeobox 2 (ZEB2)], and that SIP1 plays a key role in the TGF- $\beta 1$ signaling pathway. The knockdown of SIP1 blocks the TGF- $\beta 1$-mediated suppression of E-cadherin, suggesting that through SIP1 modulation, TGF $\beta 1$ regulates the expression of E-cadherin, EMT and fibrosis (14). Taken together, these results suggest that Smad3 and miR-192 are involved in TGF- $\beta 1$-mediated EMT.

Vascular endothelial growth factor (VEGF) is a growth factor that is involved in angiogenesis and vasculogenesis. In the kidneys, VEGF is mainly expressed in glomerular podocytes and tubular epithelial cells (16). Previous studies have illustrated that VEGF reduces the severity of disease in several experimental models of kidney disease, such as anti-Thy1 glomerulonephritis, thrombotic microangiopathy glomerulonephritis and anti-glomerular basement membrane glomerular nephritis (17-19). Other studies have also documented a reduction in VEGF expression in renal interstitial fibrosis (20-22). In our previous study, we also demonstrated that in mouse model of unilateral ureteral obstruction (UUO), the expression of VEGF prevented renal interstitial fibrosis and EMT, and that in human renal tubular epithelial cells, VEGF directly inhibited TGF- $\beta 1$-induced EMT (23).

The PI3K/Akt signaling pathway is one of the major pathways in which VEGF plays a role (24-27). On the other hand, LY294002 is a protein kinase inhibitor that blocks the phosphatidylinositol-3 kinase (PI3K) cell signaling pathway.

The data mentioned above suggest that VEGF protects renal tubular epithelial cells and that Smad3 and miR-192 are involved in the development of TGF- $\beta 1$-induced renal tubular EMT. Therefore, in this study, we aimed to further elucidate the mechanisms by which VEGF suppresses EMT, as well as to investigate the role of Smad3, miR-192, Smad2 and Smad4 in this process.

\section{Materials and methods}

Reagents. Rh-TGF- $\beta 1$ was purchased from R\&D Systems (Minneapolis, MN, USA). Anti- $\alpha$-SMA was obtained from Abcam (Cambridge, UK); anti-E-cadherin, anti-Smad3, anti-p-Smad3, anti-Smad2, anti-Smad4 and LY294002 were obtained from Cell Signaling Technology, Inc. (Danvers, MA, USA). The Hairpin-it ${ }^{\mathrm{TM}}$ miRNA quantitative PCR kit was purchased from Genepharma (Shanghai GenePharma Co. Ltd, China) TRIzol reagent was obtained from Life Technologies/BRL (Rockville, MD, USA). M-MLV reverse transcriptase, dNTP, Oligo(dT) primer and Taq polymerase were purchased from Promega (Madison, WI, USA). The BCA protein assay kits were purchased from Beyotime (Haimen, China). The MTT kit was purchased from Beijing Applygen Technologies Inc. (Beijing, China). DMEM-F12 and fetal bovine serum were purchased from HyClone Laboratories Inc. (Logan, UT, USA). The VEGF ELISA kit was purchased from R\&D Systems.

Construction of human kidney cortex (HKC) cells stably expressing VEGF. The full-length VEGF121 and VEGF165 sequences were used to create the pBuDCE4.1 expression vectors. VEGF121 was under the control of the CMV promoter and VEGF165 was under the control of the EF-1 $\alpha$ promoter. The vectors contained a Zeocin resistance cassette. The constructs were sequenced and tested for Zeocin resistance. The correct final construct was designated as Z7842-2. The Z7842-2 plasmid was introduced into HKC cells by electroporation, and the stable clones were selected in a gradual increase in the concentration of Zeocin. The expression of VEGF was detected by measuring the VEGF concentration in the supernatant by ELISA. The detected concentration of VEGF in the Z7842-2 HKC supernatant was $1210.061 \mathrm{pg} / \mathrm{ml}$, which was 10.72 -fold higher than the control cells $(\mathrm{p}<0.05)$. The ELISA results confirmed that we successfully established HKC cells stably overexpressing VEGF (HKC-SOEV cells).

HKC culture. HKC cells were cultured in Dulbecco's modified Eagle's medium/Ham's F-12 (DMEM-F12) containing $10 \%$ fetal bovine serum and grown at $37^{\circ} \mathrm{C}$ and $5 \% \mathrm{CO}_{2}$ in a humidified incubator. Cells were passaged with $0.25 \%$ trypsin digestion. The medium was changed every day. When the cells reached $70-80 \%$ confluence, the medium was replaced with serum-free medium for $24 \mathrm{~h}$ and then the cells were divided into the indicated experimental groups. All experiments were repeated 3 times. The cultured cells were divided into the following experimental groups: group A, normal untreated HKC cells; group B, normal HKC cells treated with TGF- $\beta 1$ $(5 \mu \mathrm{g} / \mathrm{l})$ for 24 or $48 \mathrm{~h}$; group C, HKC-SOEV cells; group D, HKC-SOEV cells treated with TGF- $\beta 1(5 \mu \mathrm{g} / 1)$ for 24 or $48 \mathrm{~h}$; and group E, HKC-SOEV cells co-treated with TGF- $\beta 1$ $(5 \mu \mathrm{g} / \mathrm{l})$ and LY294002 $(20 \mu \mathrm{mol} / \mathrm{l})$ for 24 or $48 \mathrm{~h}$.

Cell proliferation and toxicity detection. HKC cells were incubated with various concentrations of the PI3K-Akt signaling pathway inhibitor, LY294002 (0, 6.25, 12.5, 25, and $50 \mu \mathrm{mol} / \mathrm{l})$, for $48 \mathrm{~h}$ and then cell proliferation was analyzed by MTT assay. Cytotoxicity was analyzed using the lactate dehydrogenase (LDH) release assay according to the manufacturer's instructions.

Quantitative PCR (real-time PCR). RNA from the HKC cells was isolated using the TRIzol One Step Isolation kit according to the manufacturer's instructions. The conditions for reverse transcription reaction were as follows: $16^{\circ} \mathrm{C}$ for $30 \mathrm{~min}$, followed by $42^{\circ} \mathrm{C}$ for $30 \mathrm{~min}$ and $85^{\circ} \mathrm{C}$ for $10 \mathrm{~min}$. The real-time quantitative PCR reaction mix comprised of realtime PCR buffer, miR-specific primer set $(5 \mu \mathrm{M})$, miRNA RT product, Taq DNA polymerase $(5 \mathrm{U} / \mu \mathrm{l})$ and $\mathrm{ddH}_{2} \mathrm{O}$ to a final volume of $20 \mu \mathrm{l}$. The real-time quantitative PCR conditions were as follows: $95^{\circ} \mathrm{C}$ for $3 \mathrm{~min}$ followed by 40 cycles of $95^{\circ} \mathrm{C}$ for $12 \mathrm{sec}$ and $62^{\circ} \mathrm{C}$ for $40-60 \mathrm{sec}$. By selecting SYBR detection dye, ROX can be used as a calibration dye. Detection was set at $62^{\circ} \mathrm{C}$. In order to reach the set threshold cycle number (Ct value), the real-time quantitative PCR fluorescent signal was measured in each reaction tube. U6 was used as the internal control, and the miRNA results were measured using the relative quantification method, in which $2^{-\Delta \Delta \mathrm{Ct}}$ indicates the relative fold of expression compared to the control. $\Delta \Delta \mathrm{Ct}$ $=(\mathrm{Ct} \text { of miRNA }-\mathrm{Ct} \text { of U6) })_{\text {treatment group }}-(\mathrm{Ct}$ of miRNA $-\mathrm{Ct}$ of U6) control group. $_{\text {. }}$ 
Western blot analysis. The cells in each group were washed with cold phosphate-buffered saline (PBS) 3 times and then lysed in $100 \mu \mathrm{l}$ RIPA buffer containing protease $(100 \mu \mathrm{g} / \mathrm{ml})$ and phosphatase $(1 \mathrm{mM})$ inhibitors at $4^{\circ} \mathrm{C}$ for $30 \mathrm{~min}$. The samples were then centrifuged at $12,000 \mathrm{rpm}$ for $10 \mathrm{~min}$. The protein concentration was determined using a BCA protein assay kit, and whole lysates were mixed with an equal amount of $2 \mathrm{X}$ SDS loading buffer $(125 \mathrm{mmol} / \mathrm{l}$ Tris- $\mathrm{HCl}, 4 \%$ SDS, $20 \%$ glycerol, $100 \mathrm{mmol} / \mathrm{l}$ DTT and $0.2 \%$ bromophenol blue). Samples were heated at $100^{\circ} \mathrm{C}$ for $10 \mathrm{~min}$ and then separated on SDS-polyacrylamide gels. The separated proteins were then transferred onto a poly vinylidene difluoride (PVDF) membrane. The membrane blots were first probed with a primary antibody. Following incubation with horseradish peroxidase-conjugated secondary antibody, autoradiograms were used to visualize protein bands using an enhanced chemiluminescent system. The signals were measured on a UVI Gel image analysis system (UVI soft UVI band windows application V97.04), which scanned and recorded the intensity of the optical density. The primary antibodies that we used included anti-Smad3 $(1: 1,000)$, anti-p-Smad3 (1:100), anti-Smad2 (1:1,000), anti-Smad4 $(1: 1,000)$, anti- $\alpha$-SMA $(1: 800)$, anti-E-cadherin $(1: 600)$ and anti-GAPDH $(1: 10,000)$. The results were normalized to the signal intensity of GAPDH, which was used as an internal control.

Confocal microscopy. Cells were washed with PBS and then fixed in $4 \%$ formaldehyde for $10 \mathrm{~min}$, followed by a wash with $0.2 \%$ PBS for $5 \mathrm{~min}$. The cells were then incubated with sheep serum for $10 \mathrm{~min}$ and $0.5 \%$ Triton-100 at room temperature for $15 \mathrm{~min}$. The cells were then washed again in $0.2 \%$ PBS for 5 min and a rabbit anti-human E-cadherin antibody was added at a dilution of 1:100 or rabbit anti-human SMA at a dilution of 1:100. The cells were incubated with the antibodies at $4^{\circ} \mathrm{C}$ overnight and then washed 3 times with $0.2 \%$ PBS for $5 \mathrm{~min}$ each the following day. They were then incubated with goat anti-mouse rhodamine-labeled $\operatorname{IgG}$ at a dilution of 1:50 and goat anti-rabbit FITC-labeed IgG at a dilution of 1:50 at room temperature for $1 \mathrm{~h}$. The cells were then washed with $0.2 \%$ PBS 3 times for 5 min each. Finally, a fluorescent anti-quenching agent in 5\% PBS-glycerol was incubated with the cells. Microscopy was performed with a Leica TCS SP2 AOBS confocal microscope (Leica Micro-Systems, Heidelberg, Germany) using an excitation wavelength of $488 \mathrm{~nm}$ from an Argon laser and an emission spectra between 520 and $570 \mathrm{~nm}$. Collection parameters remained constant for all samples.

Statistical analysis. SPSS v11.5 software (SPSS, Inc., Chicago, IL, USA) was used for statistical analysis. All data are presented as the means \pm standard deviation (SD) and expressed using a significant difference test with single analysis of variance (ANOVA). A p-value $<0.05$ was considered to indicate a statistically significant difference.

\section{Results}

Effect of LY294002 on HKC cell proliferation and its toxicity. The results from the MTT and LDH assays demonstrated that at concentrations $<25 \mu \mathrm{mol} / 1$, LY294002 had no effects on HKC cell proliferation and did not induce significant cytotoxic effects.
A

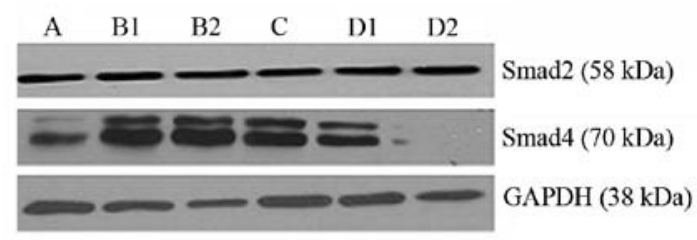

B

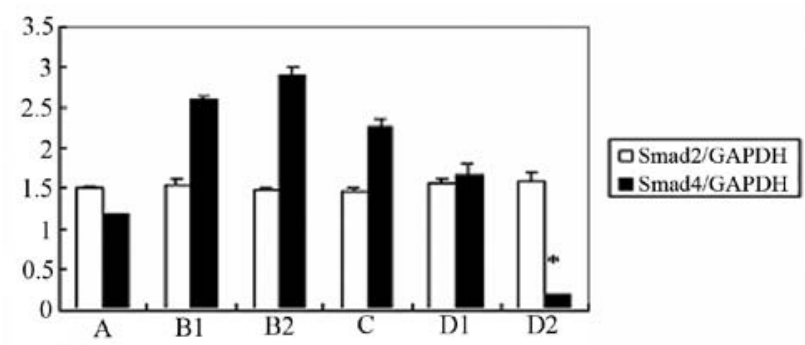

Figure 1. Western blot analysis of the expression of Smad2 and Smad4 in each group of cells. (A) The expression of Smad2 and Smad4 in each group. (B) Bar graph of the ratio of Smad2/GAPDH and Smad4/GAPDH by optical density measurement. The results are presented as the means \pm SD of 3 independent experiments. Group A, normal untreated human kidney cells (HKC cells); group B1, normal HKC cells treated with TGF- $\beta 1$ for $24 \mathrm{~h}$; group B2, normal HKC cells treated with transforming growth factor- $\beta 1$ (TGF- $\beta 1$ ) for $48 \mathrm{~h}$; group C, HKC-SOEV cells; group D1, HKC-SOEV cells treated with TGF- $\beta 1$ for $24 \mathrm{~h}$; and group D2, HKC-SOEV cells treated with TGF- $\beta 1$ for 48 h. TGF- $\beta 1$ and/or VEGF did not alter the expression of Smad2. TGF- $\beta 1$ increased the expression of Smad4, while VEGF reduced Smad4 expression in the cells treated with TGF- $\beta 1$. * $\mathrm{p}<0.05$ compared to groups A, B1, B2 and C.

Comparison of the expression of Smad 2 and Smad4 upon the indicated treatments. The western blot analysis results indicated that TGF- $\beta 1$ and/or VEGF did not alter the expression of Smad2. TGF- $\beta 1$ increased Smad4 expression, while VEGF reduced Smad4 expression. The expression of Smad4 in the HKC-SOEV cells stimulated with TGF- $\beta 1$ for $48 \mathrm{~h}$ was lower than that in the other groups $(\mathrm{p}<0.05)($ Fig. 1).

Comparison of the expression of p-Smad3 and Smad3 upon the indicated treatments. The western blot analysis results revealed that the expression of $\mathrm{p}-\mathrm{Smad} 3$ and $\mathrm{Smad} 3$ was lower in group D compared to group B ( $<<0.05)$ (Fig. $2 \mathrm{~A}$ and B). The ratio of $\mathrm{p}-\mathrm{Smad} 3 / \mathrm{Smad} 3$ expression was significantly lower in group $\mathrm{D}$, compared to that in group $\mathrm{B}(\mathrm{p}<0.05)$ (Fig. $2 \mathrm{C})$.

Gene expression of miR-192 and Smad3 in the various HKC cell groups. We found that in normal HKC cells, the expression of miR-192 was increased following treatment with TGF- $\beta 1$ for $48 \mathrm{~h}(\mathrm{p}<0.05)$; however, in the HKC-SOEV cells stimulated with TGF- $\beta 1$, it was significantly lower $(\mathrm{p}<0.05)$. When the HKC-SOEV cells were co-treated with TGF- $\beta 1$ and LY294002 for $24 \mathrm{~h}$, the expression of miR-192 was higher compared to the cells treated with TGF- $\beta 1$ alone $(\mathrm{p}<0.05)$. (Fig. 3A) The treatment of normal HKC cells with TGF- $\beta 1$ induced Smad 3 expression, as observed in group B $(p<0.05)$. We also observed a reduction in $\mathrm{Smad} 3$ expression in group C compared to group A. Moreover, the expression of Smad3 in group $\mathrm{D}$ was lower compared to that in group $\mathrm{B}(\mathrm{p}<0.05)$. By contrast, in group E, the induction of Smad3 expression 
A

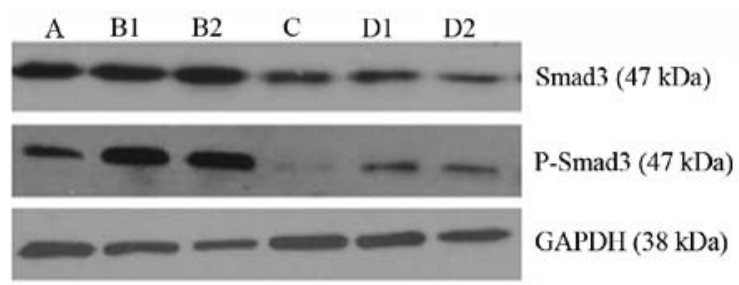

B

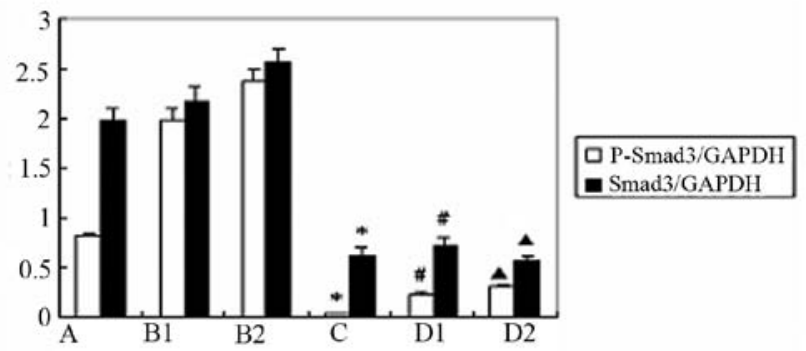

C

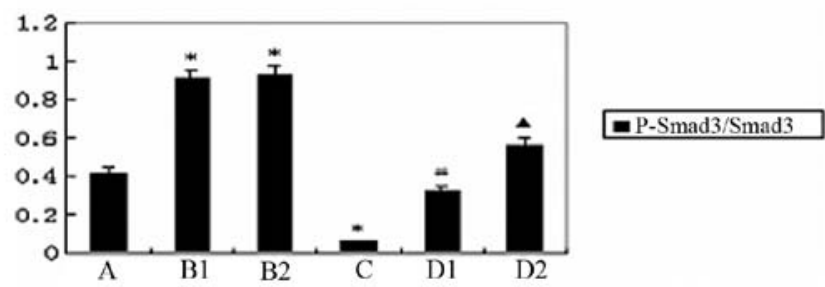

Figure 2. Western blot analysis of the expression of Smad3 and p-Smad3 in each group of cells. (A) The expression of $\mathrm{Smad} 3$ and $\mathrm{p}-\mathrm{Smad} 3$ in each group. (B) Bar graph of the ratio of Smad3/GAPDH and p-Smad3/GAPDH by optical density measurement. (C) Bar graph of the ratio of p-Smad3/Smad3 by optical density measurement. The results are presented as the means \pm SD of 3 independent experiments. Group A, normal untreated human kidney cells (HKC cells); group B1, normal HKC cells treated with transforming growth factor- $\beta 1$ (TGF- $\beta 1$ ) for $24 \mathrm{~h}$; group B2, normal HKC cells treated with TGF- $\beta 1$ for $48 \mathrm{~h}$; group C, HKC-SOEV cells; group D1, HKC-SOEV cells treated with TGF- $\beta 1$ for $24 \mathrm{~h}$; and group D2, HKC-SOEV cells treated with TGF- $\beta 1$ for $48 \mathrm{~h}$. TGF- $\beta 1$ induced $\mathrm{p}-\mathrm{Smad} 3$ expression, but VEGF inhibited Smad3 and p-Smad3 expression. "p $<0.05$ compared to group A, ${ }^{\#} \mathrm{p}<0.05$ compared to group B1, ${ }^{\wedge} \mathrm{p}<0.05$ compared to group B2.

was clearly restored upon co-treatment with TGF- $\beta 1$ and LY294002 (p<0.05) (Fig. 3B).

Comparison of the expression of E-cadherin and $\alpha$-SMA expression upon the indicated treatments. The western blot analysis and confocal microscopy results indicated that the expression of $\alpha$-SMA was significantly reduced in group D compared to group B $(\mathrm{p}<0.05)$ (Figs. $4 \mathrm{~A}$ and $\mathrm{B}$ and $5 \mathrm{~A})$. By contrast, the expression of E-cadherin increased in group $D$ compared to group $\mathrm{B}(\mathrm{p}<0.05)$. (Figs. $4 \mathrm{~A}$ and $\mathrm{B}$ and $5 \mathrm{~B})$.

\section{Discussion}

Renal interstitial fibrosis is a common pathological process that occurs during the development of a variety of chronic
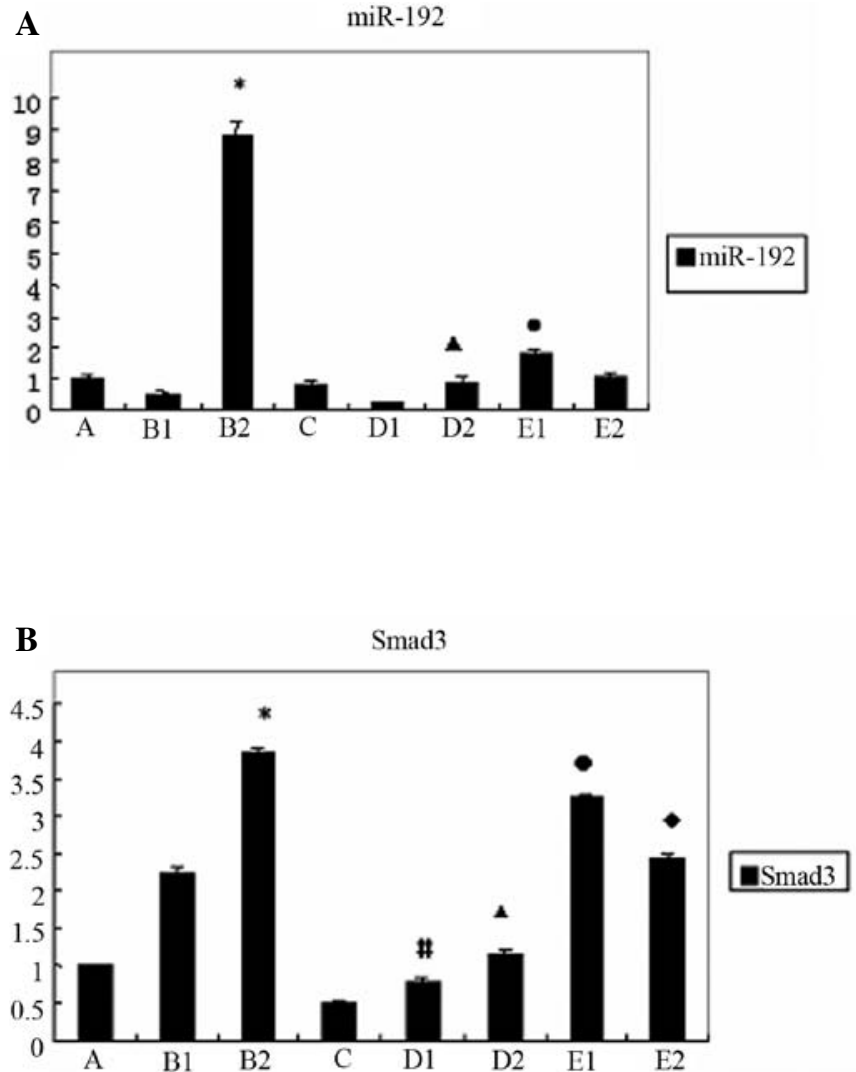

Figure 3. Expression of miR-192 and Smad3 in each treatment group as shown by real-time quantitative PCR. (A) miR-192 gene expression. (B) Smad3 gene expression. The results are presented as the means \pm SD of 3 independent experiments. Group A, normal untreated human kidney cells (HKC cells); group $\mathrm{B} 1$, normal $\mathrm{HKC}$ cells treated with transforming growth factor- $\beta 1$ (TGF- $\beta 1$ ) for $24 \mathrm{~h}$; group B2, normal HKC cells treated with TGF- $\beta 1$ for $48 \mathrm{~h}$; group C, HKC-SOEV cells; group D1, HKC-SOEV cells treated with TGF- $\beta 1$ for $24 \mathrm{~h}$; group D2, HKC-SOEV cells treated with TGF- $\beta 1$ for $48 \mathrm{~h}$; group E1, representative HKC-SOEV cells co-treated with TGF- $\beta 1$ and LY294002 for $24 \mathrm{~h}$; and group E2, representative HKC-SOEV cells treated with TGF- $\beta 1$ and LY294002 for $48 \mathrm{~h}$. The results are presented as the means \pm SD of 3 independent experiments. TGF- $\beta 1$ induced miR-192 and Smad 3 expression, which was suppressed by VEGF. ${ }^{*} \mathrm{p}<0.05$ compared to group $\mathrm{A} ;{ }^{*} \mathrm{p}<0.05$ compared to group $\mathrm{B} 1 ;{ }^{\mathrm{A}} \mathrm{p}<0.05$ compared to group $\mathrm{B} 2 ;{ }^{\bullet} \mathrm{p}<0.05$ compared to group $\mathrm{D} 1$ and $\bullet$ p $<0.05$ compared to group D2.

kidney diseases, consequently leading to end-stage renal failure. VEGF is a growth factor for endothelial cells and not only plays an important role in maintaining the integrity of vascular endothelial cells, but is also an important survival factor for renal tubular epithelial cells and is involved in renal tubular formation (28-30). Our previous studies confirmed that VEGF inhibits TGF- $\beta 1$-induced EMT $(23,31)$.

TGF- $\beta 1$-induced EMT has been widely documented in the literature $(32,33)$. In this study, we found that the treatment of normal HKC cells with TGF- $\beta 1$ resulted in a higher level of $\alpha$-SMA expression. In addition, the treatment had an opposite effect on E-cadherin expression. Compared to HKC-SOEV cells, the treatment of normal HKC cells with TGF- $\beta 1$ suppressed E-cadherin expression, but enhanced $\alpha$-SMA expression. When the HKC-SOEV cells were co-treated with TGF- $\beta 1$ and LY294002, the effect of VEGF was weakened. These results strongly suggest that VEGF inhibits TGF- $\beta 1$ induced EMT, which is consistent with the results presented in our previous studies $(23,31)$. 
A

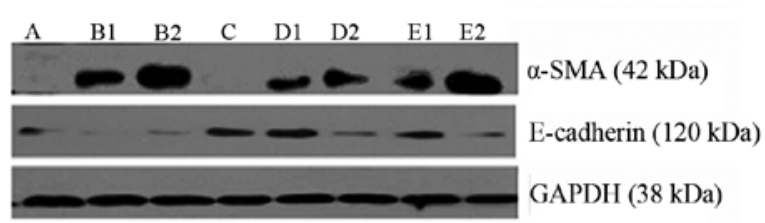

B

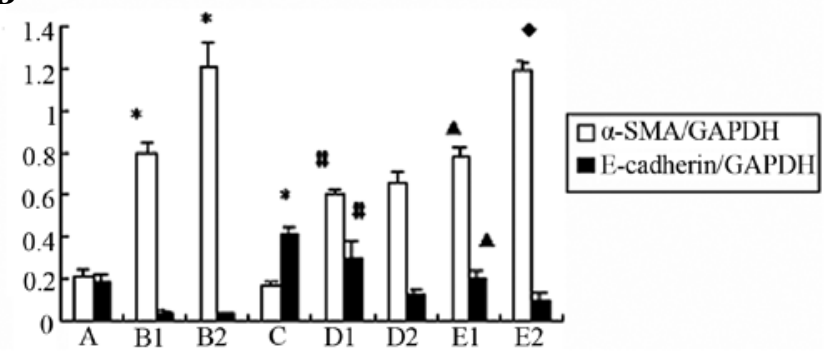

Figure 4. Western blot analysis of the expression of $\alpha$-smooth muscle actin $(\alpha$-SMA) and E-cadherin. (A) The expression of $\alpha$-SMA and E-cadherin in each group. (B) Diagram of the ratio of $\alpha$-SMA/GAPDH and E-cadherin/GAPDH by optical density measurement. The results are presented as the means \pm SD of 3 independent experiments. Group A, normal untreated HKC cells; group $\mathrm{B} 1$, normal $\mathrm{HKC}$ cells treated with transforming growth factor- $\beta 1$ (TGF- $\beta 1$ ) for $24 \mathrm{~h}$; group B2, normal HKC cells treated with TGF- $\beta 1$ for $48 \mathrm{~h}$; group C, HKC-SOEV cells; group D1, HKC-SOEV cells treated with TGF- $\beta 1$ for $24 \mathrm{~h}$; group D2, HKC-SOEV cells treated with TGF- $\beta 1$ for $48 \mathrm{~h}$; group E1, representative HKC-SOEV cells co-treated with TGF- $\beta 1$ and LY294002 for $24 \mathrm{~h}$; and group E2, representative HKC-SOEV cells treated with TGF- $\beta 1$ and LY294002 for $48 \mathrm{~h}$. TGF- $\beta 1$ increased $\alpha$-SMA and inhibited E-cadherin expression, but VEGF decreaced $\alpha$-SMA and increased E-cadherin expression. " $\mathrm{p}<0.05$ compared to group $\mathrm{A} ;{ }^{\#} \mathrm{p}<0.05$ compared to group $\mathrm{B} 1 ;{ }^{\wedge} \mathrm{p}<0.05$ compared to group D1; and $" \mathrm{p}<0.05$ compared to group D2.

The TGF- $\beta 1 /$ Smad signaling pathway is an important mechanism through which TGF- $\beta 1$ induces tubular EMT $(3-5,34)$. Smad2, Smad 3 and Smad4 are direct mediators of the TGF- $\beta$ signaling pathway (35). In this study, we found that TGF- $\beta 1$ and/or VEGF did not alter the expression of Smad2; however, TGF- $\beta 1$ increased the expression of Smad4. To our surprise, VEGF did not alter Smad4 alone, but reduced Smad4 expression in the cells treated with TGF- $\beta 1$. This effect was more pronounced when the HKC-SOEV cells were stimulated with TGF- $\beta 1$ for $48 \mathrm{~h}$. The mechanism involved however, remains unclear. Hence, the action of Smad2 and Smad4 was scant in the procedure of EMT. However, it is also important to determine the effect of VEGF on Smad3. Smad3 has been shown to play a critical role in this pathway $(11,15,35)$. Our study verified that in the HKC cells, treatment with TGF- $\beta 1$ induced Smad3 expression, whereas in the HKC-SOEV cells, the effect of TGF- $\beta 1$ on Smad3 was reduced, suggesting that VEGF suppresses the expression of Smad3. In addition, treatment with TGF- $\beta 1$ enhanced the $\mathrm{p}-\mathrm{Smad} 3 / \mathrm{Smad} 3$ expression ratio in normal HKC cells. However, in the HKC-SOEV cells, the enhancement of this ratio was significantly reduced, suggesting that VEGF suppresses Smad3 phosphorylation. Importantly, treatment with LY294002 significantly diminished the effect of VEGF, further illustrating that VEGF suppresses Smad3 and p-Smad3. Our results also demonstrated that VEGF inhibited TGF- $\beta 1$-mediated EMT. Therefore, it is possible that VEGF inhibits EMT partly through suppressing Smad3 expression and phosphorylation. The change in Smad3 expression was much more pronounced than the change in the expression of Smad2 and Smad4, which indicates that Smad3 is the key modulator. These results are in agreement with those from a previous study (15).

In a previous study, Perera reported that miR-192 promoter sequences contain a highly conserved Ets-1 binding site (36); TGF- $\beta 1$ can influence the Ets-1 regulation of miR-192 expression (36). Our study demonstrated that following treatment with TGF- $\beta 1$ for $48 \mathrm{~h}$, the expression of miR-192 significantly increased in HKC cells, indicating that in the human tubular
$\mathbf{A}$
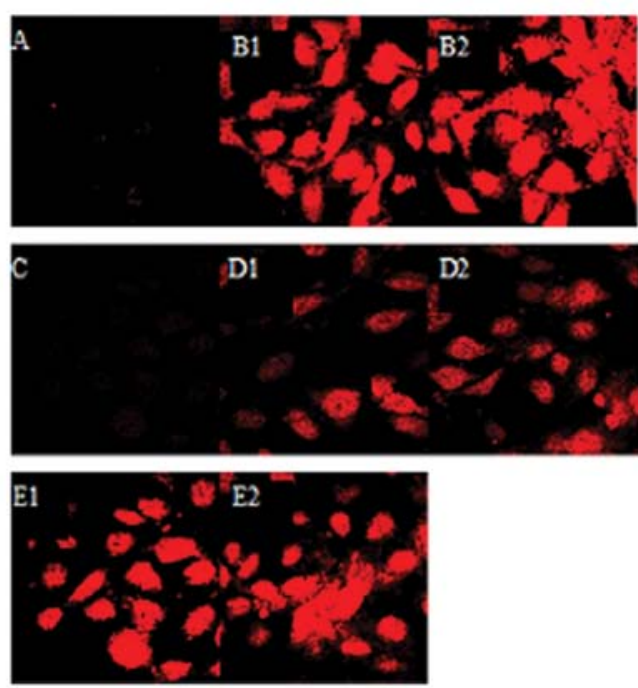

B
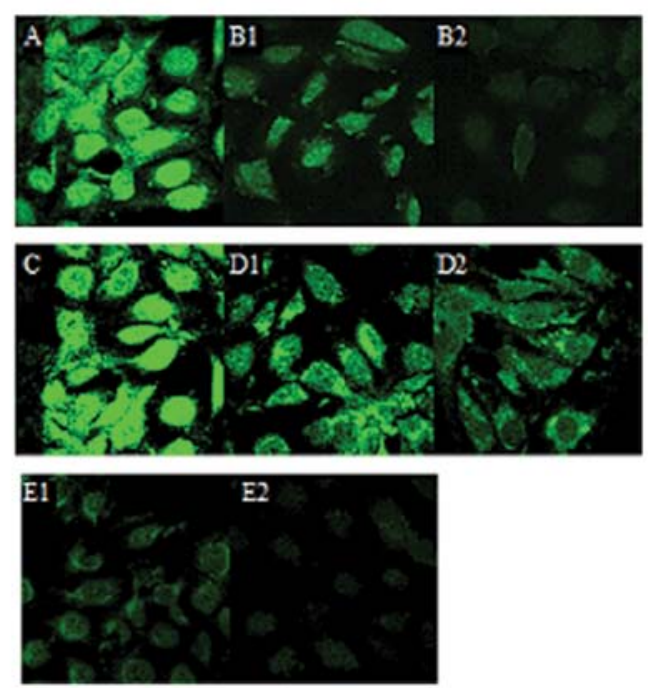

Figure 5. Confocal microscopy of the expression of $\alpha$-smooth muscle actin ( $\alpha$-SMA) and E-cadherin. (A) Images of confocal microscopy showing the expression of $\alpha$-SMA (x600). (B) Images of confocal microscopy showing the expression of E-cadherin (x600). Group A, normal untreated human kidney cell (HKC cells); group B1, normal HKC cells treated with transforming growth factor- $\beta 1$ (TGF- $\beta 1$ ) for 24 h; group B2, normal HKC cells treated with TGF- $\beta 1$ for 48 h; group C, HKC-SOEV cells; group D1, HKC-SOEV cells treated with TGF- $\beta 1$ for 24 h; group D2, HKC-SOEV cells treated with TGF- $\beta 1$ for 48 h; group E1, representative HKC-SOEV cells co-treated with TGF- $\beta 1$ and LY294002 for $24 \mathrm{~h}$; and group E2, representative HKC-SOEV cells treated with TGF- $\beta 1$ and LY294002 for $48 \mathrm{~h}$. TGF- $\beta 1$ increased $\alpha$-SMA and inhibited E-cadherin expression, but VEGF decreaced $\alpha$-SMA and increased E-cadherin expression. 
epithelium, TGF- $\beta 1$ can also stimulate miR-192; these results are consistent with those from a previous study (12). In our study, we observed that in the HKC-SOEV cells, treatment with TGF- $\beta 1$ for $48 \mathrm{~h}$ failed to induce miR-192 expression, indicating that VEGF inhibits TGF- $\beta 1$-induced miR-192 expression. Treatment with the PI3K inhibitor, LY294002, which impairs VEGF signal transduction, significantly increased the expression of miR-192, further demonstrating that VEGF inhibited the expression of miR-192. Our study results strongly suggest that VEGF inhibits TGF- $\beta 1$-induced EMT, and that TGF- $\beta 1$ upregulates miR-192 expression in the renal tubular epithelium; therefore, VEGF suppresses EMT through the downregulation of miR-192.

Evidence supporting the interaction of Smad3 with miR-192 also came from the findings that there are conserved Smad3 binding sites in the promoter region of miR-192 and that Smad3 is able to interact with individual promoter regions as detected by Chip assay (12). In a previous study, it was demonstrated that in a mouse model of UUO, the expression of miR-192 was significantly increased in wild-type mice expressing Smad3, while it was downregulated in Smad3 gene knockout mice (12). This indicates that Smad3 and miR-192 are closely correlated. In our study, we confirmed that VEGF suppressed Smad3 in the process of TGF- $\beta 1$-induced EMT. We found that VEGF significantly inhibited the expression of miR-192. miR-192 is a specific microRNA targeting Smad3, that is, miR-192 is the downstream target gene, and Smad3 may also positively regulate downstream specific miR-192 to mediate renal fibrosis (11). Thus, we inferred that VEGF repressed Smad3 and then reduced the expression of miR-192, subsequently inhibiting EMT induced by TGF- $\beta 1$. To the best of our knowledge, this is the first study to report such an observation.

In conclusion, the data presented in this study indicate that VEGF inhibits the expression of Smad3 and subsequently reduces miR-192 expression, thus suppressing EMT, and thereby alleviating fibrosis. Therefore, our study provides a new basis for the clinical application of VEGF in the treatment of early chronic renal interstitial fibrosis.

\section{Acknowledgements}

This study was supported by a grant from the National Natural Science Foundation of China (no. 30570854).

\section{References}

1. Kalluri R and Neilson EG: Epithelial-mesenchymal transition and its implications for fibrosis. J Clin Invest 112: 1776-1784, 2003.

2. Wynn TA: Cellular and molecular mechanisms of fibrosis. J Pathol 214: 199-210, 2008.

3. Roxburgh SA, Murphy M, Pollock CA and Brazil DP: Recapitulation of embryological programmes in renal fibrosisthe importance of epithelial cell plasticity and developmental genes. Nephron Physiol 103: 139-148, 2006.

4. Khew-Goodall $\mathrm{Y}$ and Wadham $\mathrm{C}$ : A perspective on regulation of cell-cell adhesion and epithelial-mesenchymal transition: known and novel. Cells Tissues Organs 179: 81-86, 2005.

5. Grande MT and López-Novoa JM: Fibroblast activation and myofibroblast generation in obstructive nephropathy. Nat Rev Nephrol 5: 319-328, 2009.

6. Neilson EG: Setting a trap for tissue fibrosis. Nat Med 11: 373-374, 2005

7. Selman M and Pardo A: Role of epithelial cells in idiopathic pulmonary fibrosis: from innocent targets to serial killers. Proc Am Thorac Soc 3: 364-372, 2006.
8. Liu Y: Epithelial to mesenchymal transition in renal fibrogenesis: pathologic significance, molecular mechanism, and therapeutic intervention. J Am Soc Nephrol 15: 11-12, 2004.

9. Holian J, Qi W, Kelly DJ, Zhang Y, Mreich E, Pollock CA and Chen XM: Role of Kruppel-like factor 6 in transforming growth factor $\beta 1$-induced epithelial-mesenchymal transition of proximal tubule cells. Am J Physiol Renal Physiol 295 : F1388-F1396, 2008.

10. Lan HY: Tubular epithelial-myofibroblast transdifferentiation mechanisms in proximal tubule cells. Curr Opin Nephrol Hypertens 12: 25-29, 2003.

11. Lan HY: Diverse roles of TGF- $\beta / \mathrm{Smads}$ in renal fibrosis and inflammation. Int J Biol Sci 7: 1056-1067, 2011.

12. Chung AC, Huang XR, Meng X and Lan HY: miR-192 mediates TGF-beta/Smad3-driven renal fibrosis. J Am Soc Nephrol 21: 1317-1325, 2010.

13. Wang B,Herman-Edelstein M,Koh P,Burns W, Jandeleit-Dahm K, Watson A, Saleem M, Goodall GJ, Twigg SM, Cooper ME and Kantharidis P: E-cadherin expression is regulated by miR-192/215 by a mechanism that is independent of the profibrotic effects of transforming growth factor-beta. Diabetes 59: 1794-1802, 2010.

14. Kato M, Zhang J, Wang M, Lanting L, Yuan H, Rossi JJ and Natarajan R: MicroRNA-192 in diabetic kidney glomeruli and its function in TGF-beta-induced collagen expression via inhibition of E-box repressors. Proc Natl Acad Sci USA 104: 3432-3437, 2007.

15. Sato M, Muragaki Y, Saika S, Roberts AB and Ooshima A: Targeted disruption of TGF-beta1/Smad3 signaling protects against renal tubulointerstitial fibrosis induced by unilateral ureteral obstruction. J Clin Invest 112: 1486-1494, 2003.

16. Schrijvers BF, Flyvbjerg A and De Vriese AS: The role of vascular endothelial growth factor (VEGF) in renal pathophysiology. Kidney Int 65: 2003-2017, 2004.

17. Wada Y, Morioka T, Oyanagi-Tanaka Y, Yao J, Suzuki Y, Gejyo F, Arakawa $\mathrm{M}$ and Oite T: Impairment of vascular regeneration precedes progressive glomerulosclerosis in anti-Thyl glomerulonephritis. Kidney Int 61: 432-443, 2002.

18. Kim YG, Suga SI, Kang DH, Jefferson JA, Mazzali M, Gordon KL, Matsui K, Breiteneder-Geleff S, Shankland SJ, Hughes J, Kerjaschki D, Schreiner GF and Johnson RJ: Vascular endothelial growth factor accelerates renal recovery in experimental thrombotic microangiopathy. Kidney Int 58: 2390-2399, 2000.

19. Shimizu A, Masuda Y, Mori T, Kitamura H, Ishizaki M, Sugisaki Y and Fukuda Y: Vascular endothelial growth factor165 resolves glomerular inflammation and accelerates glomerular capillary repair in rat anti-glomerular basement membrane glomerulonephritis. J Am Soc Nephrol 15: 2655-2665, 2004.

20. Song YR, You SJ, Lee YM, Chin HJ, Chae DW, Oh YK, Joo KW, Han JS and Na KY: Activation of hypoxia-inducible factor attenuates renal injury in rat remnant kidney. Nephrol Dial Transplant 25: 77-85, 2010.

21. Sun D, Feng J, Dai C, Sun L, Jin T, Ma J and Wang L: Role of peritubular capillary loss and hypoxia in progressive tubulointerstitial fibrosis in a rat model of aristolochic acid nephropathy. Am J Nephrol 26: 363-371, 2006.

22. Burt LE, Forbes MS, Thornhill BA, Kiley SC and Chevalier RL: Renal vascular endothelial growth factor in neonatal obstructive nephropathy. I. Endogenous VEGF. Am J Physiol Renal Physiol 292 : F158-F167, 2007.

23. Lian YG, Zhou QG, Zhang YJ and Zheng FL: VEGF ameliorates tubulointerstitial fibrosis in unilateral ureteral obstruction mice via inhibition of epithelial-mesenchymal transition. Acta Pharmacol Sin 32 : 1513-1521, 2011.

24. Holmes K, Roberts OL, Thomas AM and Cross MJ: Vascular endothelial growth factor receptor-2: structure, function, intracellular signalling and therapeutic inhibition. Cell Signal 19: 2003-2012, 2007.

25. Kowanetz M and Ferrara N: Vascular endothelial growth factor signaling pathways: therapeutic perspective. Clin Cancer Res 12: 5018-5022, 2006.

26. Cross MJ, Dixelius J, Matsumoto T and Claesson-Welsh L: VEGF-receptor signal transduction. Trends Biochem Sci 28: 488-494, 2003.

27. Olsson AK, Dimberg A, Kreuger J and Claesson-Welsh L: VEGF receptor signalling - in control of vascular function. Nat Rev Mol Cell Biol 7: 359-371, 2006.

28. Karihaloo A, Karumanchi SA, Cantley WL, Venkatesha S, Cantley LG and Kale S: Vascular endothelial growth factor induces branching morphogenesis/tubulogenesis in renal epithelial cells in a neuropilin-dependent fashion. Mol Cell Biol 25: 7441-7448, 2005. 
29. Kang DH, Joly AH, Oh SW, Hugo C, Kerjaschki D, Gordon KL, Mazzali M, Jefferson JA, Hughes J, Madsen KM, Schreiner GF and Johnson RJ: Impaired angiogenesis in the remnant kidney model: I. Potential role of vascular endothelial growth factor and thrombospondin-1. J Am Soc Nephrol 12: 1434-1447, 2001.

30. Katavetin P, Miyata T, Inagi R, Tanaka T, Sassa R, Ingelfinger JR, Fujita T and Nangaku M: High glucose blunts vascular endothelial growth factor response to hypoxia via the oxidative stress-regulated hypoxia-inducible factor/hypoxia-responsible element pathway. J Am Soc Nephrol 17: 1405-1413, 2006.

31. Zhou QG, Zheng FL and Hou FF: Inhibition of tubulointerstitial fibrosis by pentoxifylline is associated with improvement of vascular endothelial growth factor expression. Acta Pharmacol Sin 30: 98-106, 2009.

32. Zeisberg M, Hanai J, Sugimoto H, Mammoto T, Charytan D, Strutz F and Kalluri R: BMP-7 counteracts TGF-beta1-induced epithelial-to-mesenchymal transition and reverses chronic renal injury. Nat Med 9: 964-968, 2003.
33. Xu Y, Wan J, Jiang D and Wu X: BMP-7 counteracts TGF-beta1-induced epithelial-to mesenchymal transition in human renal proximal tubular epithelial cells. J Nephrol 22: 403-410, 2009.

34. Liu Y: Renal fibrosis: new insights into the pathogenesis and therapeutics. Kidney Int 69: 213-217, 2006.

35. Brown KA, Pietenpol JA and Moses HL: A tale of two proteins: differential roles and regulation of Smad 2 and Smad3 in TGF-beta signaling. J Cell Biochem 101: 9-33, 2007.

36. Perera RJ: A microarray-based method to profile global microRNA expression in human and mouse. Methods Mol Biol 382: 137-148, 2007. 